\section{Erosion of public health capacity should be a matter of concern for all Canadians}

Public health matters for society, and the benefits of prevention have been clearly demonstrated: ${ }^{1}$ a healthy population is a social good. Not having a disease or injury in the first place avoids much pain and suffering among patients and their families, as well as premature death. On top of this, there are significant economic benefits from prevention, both in avoided health care costs and in avoided loss of production, income, and tax revenue. ${ }^{2,3}$ Moreover, arguably, quality health care is not possible without a strong public health sector, ${ }^{4}$ which contributes in a significant way to all three goals of the "Triple Aim", a widely-used set of overall goals for the health care system: improved population health, improved patient experience of care, and reduced per capita cost of health care.,

The Editorial Board of the Canadian Journal of Public Health is thus alarmed by the ongoing erosion of public health capacity in Canada. Those concerns have been expressed in these pages several times in recent years. Public health has been characterized as "under siege" ${ }^{7}$ and "under attack". ${ }^{8}$ It has been argued that its weakening - characterized by downgrading the status of public health within governments and health authorities; eroding the independence of Medical Officers of Health; limiting the scope of public health by combining it with primary care; and decreasing funding - is a threat to both the health of the population and the sustainability of the health care system. ${ }^{9}$

Moreover, given public health's work on the most basic determinants of health and its commitment to social equity, the erosion of capacity will likely disproportionately impact populations already experiencing unacceptable health disparities - for example, Indigenous populations, who continue to experience health inequities that are rooted in unaddressed basic public health challenges and shame Canada on the international stage. ${ }^{10,11}$

Public health continues to face challenges. Several further actions that erode public health capacity have occurred in just the few short months since our last editorial. ${ }^{9}$ At a national level, the Public Health Agency of Canada has backed away from one of the key reasons it was established - to address concerns about public health capacity in Canada $^{12}$ - by eliminating both the Skills Online program $^{13}$ and the practicum awards for MPH students established in 2013. This award had "provided over $\$ 1.8 \mathrm{M}$ of funding to 17 institutions across Canada". ${ }^{14}$

At the provincial level, the most serious attack on public health has occurred recently in New Brunswick, where the government fired the former Chief Public Health Officer (CPHO) last year for no discernible reason and has moved some 70 of the 110 staff out of the Ministry of Health, spreading them across three different ministries, ${ }^{15}$ thus disrupting the cohesiveness of the public health department and undermining its ability to address important public health issues.

The reaction has been strong, with critical comments from public health professionals from across Canada in the local print media, on radio programs, and in open letters from the Canadian Network of Public Health Associations ${ }^{16}$ and the Public Health Physicians of Canada. ${ }^{17}$ Dr. Wayne McDonald, a former CPHO for New Brunswick,

\section{L'érosion des capacités en santé publique devrait préoccuper tous les Canadiens}

La santé publique importe pour la société, et les avantages de la prévention sont clairement démontrés ${ }^{1}$ : une population en bonne santé est un bien social. En prévenant les maladies et les blessures, on évite beaucoup de souffrance et de douleur (celles des patients et de leurs familles), ainsi que les décès prématurés. La prévention présente aussi d'importants avantages économiques : coûts de soins de santé évités, pertes de production évitées, revenus et recettes fiscales ${ }^{2,3}$. Sans compter qu'il est probablement impossible d'offrir des soins de santé de qualité en l'absence d'un secteur de la santé publique vigoureux ${ }^{4}$, car celui-ci contribue beaucoup aux trois branches du « triple objectif » (un ensemble d'objectifs globaux très utilisé dans le système de soins de santé) : une meilleure santé des populations et une meilleure expérience des services de santé à un meilleur coût par habitant ${ }^{5,6}$.

Le comité éditorial de la Revue canadienne de santé publique est donc alarmé par l'érosion constante des capacités en santé publique au Canada. Cette inquiétude a été exprimée plusieurs fois en ces pages ces dernières années. La santé publique a été caractérisée comme étant « en état de siège ${ }^{7}$ » et « en butte à des attaques ${ }^{8}$ ». Il a été soutenu que son affaiblissement - marqué par son déclassement au sein des gouvernements et des autorités sanitaires; par l'érosion de l'indépendance des directeurs de la santé publique/médecinshygiénistes; par la limitation de la portée de la santé publique en la combinant avec les soins primaires; et par la réduction de son financement - menace à la fois la santé de la population et la durabilité du système de soins de santé9.

De plus, comme la santé publique s'attache aux déterminants les plus fondamentaux de la santé et qu'elle adhère à l'équité sociale, l'érosion de ses capacités aura sans doute un impact démesuré sur les populations déjà sujettes à des disparités d'état de santé inacceptables - les populations autochtones, par exemple, subissent encore des inégalités de santé ancrées dans des problèmes de santé publique de base non résolus qui font honte au Canada sur la scène internationale $\mathrm{e}^{10,11}$.

La santé publique a encore des défis à relever. Plusieurs mesures qui érodent encore ses capacités ont été prises quelques mois à peine depuis notre dernier éditorial ${ }^{9}$. À l'échelle nationale, l'Agence de la santé publique du Canada a renoncé à l'une des principales raisons pour lesquelles elle a été créée (soit de répondre aux préoccupations concernant la capacité du Canada en matière de santé publique ${ }^{12}$ ) en supprimant à la fois le programme Compétences en ligne ${ }^{13}$ et les bourses de stage qui étaient octroyées aux étudiants de maîtrise en santé publique depuis 2013. Par ces bourses, plus de 1,8 million de dollars de fonds ont été consentis à 17 établissements canadiens ${ }^{14}$.

À l'échelle provinciale, l'attaque la plus grave contre la santé publique a été perpétrée récemment au Nouveau-Brunswick, où le gouvernement a congédié la médecin-hygiéniste en chef l'an dernier sans raison apparente et déplacé 70 des 110 membres du personnel hors du ministère de la Santé en les répartissant entre trois autres ministères ${ }^{15}$, ce qui a perturbé la cohésion du Service de santé publique et miné sa capacité de résoudre d'importants problèmes de santé publique.

Les réactions ont été vives; des professionnels de la santé publique de tout le Canada ont exprimé leur opposition dans la presse écrite locale, à la radio et dans les lettres ouvertes du Réseau canadien des associations de santé publique ${ }^{16}$ et des Médecins de santé publique du Canada ${ }^{17}$. $\mathrm{D}^{\mathrm{r}}$ Wayne McDonald, ancien médecin-hygiéniste en chef du Nouveau-Brunswick, a qualifié ces 
has labeled the changes "a recipe for disaster", ${ }^{18}$ while Dr. Jim Talbot, a former CPHO of Alberta, has written that it "makes no sense" and "displays a profound ignorance of what public health is and what it does". ${ }^{19}$ Despite these strong expressions of concern, the government of New Brunswick has gone ahead with its changes.

Public health capacity is being undermined in Ontario too, the last bastion of municipal public health in Canada. The recent Report of the Minister's Expert Panel on Public Health (Government of Ontario, $2017)^{20}$ proposes a much closer relationship between public health and the health care system and an erosion of its links to local government. These proposals are problematic because most of what determines our health lies outside of the scope of the health care system. The Council of Medical Officers of Health, the Association of Municipalities of Ontario, the Association of Local Public Health Agencies, and the Ontario Public Health Association have all rejected or raised serious objections to the recommendations of this report. ${ }^{21-24}$

Even Canada's provincial and territorial CPHOs, not known for speaking out critically on government policy, have recently raised the alarm. Pointing to the 2010 Federal, Provincial, and Territorial Ministers' Declaration on Prevention and Promotion, ${ }^{25}$ the CPHOs state: "Reviving a national prevention agenda is key to sustainability of health care in Canada" and they "implore health ministers to reaffirm commitment to the principles outlined in the declaration", ${ }^{26}$ which include making prevention a priority, recognizing that it is the first step in disease management and a hallmark of a quality health system.

At a time when public health is under an unrelenting attack on its capacity to carry out its central functions, it is vital that the entire public health community - all our many professional/ disciplinary and academic organizations - come together and form a united front to defend and strengthen public health's capacity to promote and protect the health of Canadians in all provinces and territories.

It is equally important that groups and organizations in society that are concerned with the sustainability of the health care system rally round and support public health. They should insist that Canada's Ministers of Health honour their 2010 commitment that "the promotion of health and the prevention of disease, disability and injury are a priority and necessary to the sustainability of the health system" and that "a better balance between prevention and treatment must be achieved". ${ }^{25}$

Finally, all those in Canada concerned with the health of the population and the sustainability of the health care system need to demand that their provincial, territorial, and federal governments cease undermining and instead commit to strengthening public health. The continued erosion of public health capacity in Canada must be reversed, and instead must be reinforced, both to improve the health of the population and to reduce the burden of disease that threatens the sustainability of the health care system. Failure to do so puts at risk both of these highly valued social benefits.

Trevor Hancock, CJPH Senior Editor, On behalf of the Editorial Board of the Canadian Journal of Public Health mesures de «recette désastreuse ${ }^{18}$ », et $\mathrm{D}^{\mathrm{r}}$ Jim Talbot, ancien médecin-hygiéniste en chef de l'Alberta, a renchéri en écrivant qu'elles n'avaient « aucun sens » et qu'elles étaient la preuve d'une profonde ignorance de la nature et du mandat de la santé publique $^{19}$. Malgré ces vives inquiétudes, le gouvernement du Nouveau-Brunswick a mis ses changements en œuvre.

Les capacités en santé publique sont également minées en Ontario, le dernier bastion de la santé publique municipale au Canada. Le récent Rapport du comité ministériel d'experts sur la santé publique (gouvernement de l'Ontario, 2017) ${ }^{20}$ propose de resserrer les liens de la santé publique avec le système de soins de santé et de relâcher ses liens avec les administrations locales. Ces propositions posent problème, car la plupart des facteurs déterminants pour notre santé ne relèvent pas du champ d'application du système de soins de santé. Le conseil des médecins-hygiénistes de la province, l'association des municipalités, l'association des organismes de santé publique locaux et l'Association pour la santé publique de l'Ontario ont tous rejeté les recommandations du rapport ou y ont opposé de sérieuses réserves ${ }^{21-24}$

Même les médecins-hygiénistes en chef (MHC) des provinces et des territoires du Canada, qui ne sont pourtant pas connus pour leurs critiques à l'endroit des politiques gouvernementales, ont sonné l'alarme dernièrement. Invoquant la Déclaration sur la prévention et la promotion ${ }^{25}$ des ministres fédéraux, provinciaux et territoriaux publiée en 2010, les MHC écrivent qu'il est essentiel à la durabilité des soins de santé au Canada de relancer un plan d'action national sur la prévention et implorent les ministres de la Santé de réaffirmer leur engagement envers les principes directeurs de la Déclaration ${ }^{26}$, c'est-à-dire de faire de la prévention une priorité, de reconnaître qu'elle est la première étape de la gestion des problèmes de santé et de reconnaître qu'elle est une caractéristique distinctive d'un réseau de la santé de qualité

À l'heure où les capacités de la santé publique de s'acquitter de ses fonctions centrales font l'objet d'attaques incessantes, il faut absolument que toute notre communauté - nos nombreuses associations professionnelles, disciplinaires et universitaires forment un front uni pour défendre et renforcer les capacités en santé publique, pour que celle-ci puisse promouvoir et protéger la santé des Canadiens dans l'ensemble des provinces et des territoires.

Il est tout aussi important que les groupes et les organisations de la société qui ont à cœur la durabilité du système de soins de santé se rallient pour soutenir la santé publique. Ils devraient insister pour que les ministres de la Santé du Canada respectent leur engagement de 2010, à savoir que " la promotion de la santé et la prévention des maladies, des incapacités et des blessures sont prioritaires et nécessaires à la viabilité du système de santé » et que " nous devons atteindre un meilleur équilibre entre la prévention et le traitement ${ }^{25}$ ».

Enfin, les citoyens qui ont le souci de la santé de la population et de la durabilité du système de soins de santé doivent exiger de leur gouvernement provincial ou territorial et du gouvernement fédéral qu'ils cessent de miner la santé publique et s'engagent plutôt à la renforcer. L'érosion continue des capacités en santé publique au Canada doit être inversée; il faut que ces capacités soient renforcées, à la fois pour améliorer la santé de la population et pour réduire la charge de morbidité qui menace la durabilité du système de soins de santé. Sinon, ces deux biens sociaux très appréciés risquent de disparaître.

Trevor Hancock, rédacteur, Au nom du comité éditorial de la Revue canadienne de santé publique 


\section{REFERENCES}

1. Rutty C, Sullivan S. This is Public Health: A Canadian History. Ottawa, ON: Canadian Public Health Association, 2010. Available at: http://www.cpha.ca/ uploads/history/book/historybook-print_all_e.pdf.

2. Merkur S, Sassi F, McDaid D. Promoting Health, Preventing Disease: Is There an Economic Case? Copenhagen, Denmark: WHO Regional Office for Europe, 2013.

3. Conference Board of Canada. Améliorer les habitudes de vie : des retombées importantes pour la santé et l'économie du Québec. Ottawa (Ontario) : The Board, 2014. Available at: http://www.conferenceboard.ca/e-library/abstract.aspx? did=6647 (Accessed November 25, 2017).

4. Hancock T. No quality health care without strong public health. CMAJ 2017; 189:E1435. PMID: 29158464. doi: 10.1503/cmaj.171287.

5. Institute for Healthcare Improvement. The IHI Triple Aim Initiative, n.d. Available at: http://www.ihi.org/Engage/Initiatives/TripleAim/Pages/default. aspx.

6. Bergevin Y, Habib B, Elicksen K, Samis S, Rochon J, Adaimé C, et al. Towards the Triple Aim of Better Health, Better Care and Better Value for Canadians: Transforming Regions into High Performing Health Systems. Ottawa, ON: Canadian Foundation for Healthcare Improvement, 2016.

7. Potvin L. Canadian public health under siege. [Editorial] Can J Public Health 2014;105(6):e401-3. PMID: 25560884. doi: 10.17269/cjph.105.4960.

8. Guyon A, Perreault R. Public health systems under attack in Canada: Evidence on public health system performance challenges arbitrary reform. Can J Public Health 2016;107(3):e326-29. PMID: 27763850. doi: 10.17269/ cjph.107.5273.

9. Guyon A, Hancock T, Kirk M, MacDonald M, Neudorf C, Sutcliffe P, et al. The weakening of public health: A threat to population health and health care system sustainability. [Editorial] Can J Public Health 2017;108(1):e1-6. PMID: 28425892. doi: 10.17269/cjph.108.6143.

10. Truth and Reconciliation Commission. Honouring the Truth, Reconciling for the Future: Summary of the Final Report of the Truth and Reconciliation Commission of Canada. Ottawa, ON: TRC, 2015.

11. United Nations, International Covenant on Civil and Political Rights. Concluding Observations on the Sixth Periodic Report of Canada (CCPR/C/CAN/CO/6). UN Human Rights Committee, 2015. Available at: http://tbinternet.ohchr.org/_layouts/treatybodyexternal/Download.aspx? symbolno=CCPR\%2FC\%2FCAN\%2FCO\%2F6\&Lang=en (Accessed November 26, 2017).

12. Public Health Agency of Canada. History. Ottawa, ON: PHAC, 2008. Available at: https://www.canada.ca/en/public-health/corporate/mandate/about-agency/ history.html (Accessed November 25, 2017).

13. Public Health Agency of Canada. Skills Online. Ottawa, ON: PHAC, 2017. Available at: https://www.canada.ca/en/public-health/services/public-healthpractice/skills-online.html (Accessed November 25, 2017).

14. Hoffman S. E-mail to Schools of Public Health from Steven J. Hoffman, Scientific Director, CIHR Institute of Population \& Public Health, October 6, 2017.

15. Government of New Brunswick. Restructuring to Allow Enhanced Alignment of Government Expertise. Press release, August 31, 2017. Available at: http:// www2.gnb.ca/content/gnb/en/news/news_release.2017.08.1162.html (Accessed September 21, 2017).

16. Canadian Network of Public Health Associations. An Open Letter to the New Brunswick Minister of Health, October 12, 2017. Available at: https://www. cpha.ca/nb_openletter (Accessed November 25, 2017).

17. Allison S. N.B. public health under siege. Telegraph J. St. John's, NB, October 17, 2017

18. Chilibeck J. 'Recipe for disaster': Former top doc slams changes to medical health office. Telegraph J. St. John's, NB, September 14, 2017. Available at: file://Users/trevor/Downloads/dr-wayne-macdonald-office-of-the-chief-medicalofficer-of-health-new-brunswick-restructuring-.html.

19. Talbot J. Weakening public health makes no sense. Telegraph J. St. John's, NB, October 25, 2017; A7.

20. Government of Ontario. Public Health Within an Integrated Health System: Report of the Minister's Panel on Public Health. Toronto, ON, 2017. Available at: http://www.health.gov.on.ca/en/common/ministry/publications/reports/ public_health_panel_17/expert_panel_report.pdf (Accessed September 26, 2017).

21. Council of Ontario Medical Officers of Health. Response to the Provincial Consultations on the Report of the Minister's Expert Panel on Public Health. Letter to the Minister of Health and Long-Term Care, October 12, 2017. Available at: http://c.ymcdn.com/sites/www.alphaweb.org/resource/collection/7BDE5E132838-4DFE-AF52-28F4A4F9A3F3/COMOH_Response_EPPH_FINAL_121017.pdf (Accessed November 25, 2017).

22. Association of Municipalities of Ontario. AMO's Response to the Expert Panel on Public Health. Briefing note, October 12. Available at: https://www.amo.on.ca/ AMO-PDFs/Briefing-Notes/2017/Expert-Panel-on-Public-Health-AMO-Response2017-10.aspx (Accessed November 25, 2017).

23. Association of Local Public Health Agencies. Letter to the Minister of Health and Long-Term Care, October 17, 2017. Available at: http://c.ymcdn.com/

\section{RÉFÉRENCES BIBLIOGRAPHIQUES}

1. Rutty C, Sullivan S. La santé publique : une histoire canadienne. Ottawa (Ontario) : Association canadienne de santé publique, 2010. Sur Internet : https://www cpha.ca/fr/cyberlivre-historique.

2. Merkur S, Sassi F, McDaid D. Promoting Health, Preventing Disease: Is There an Economic Case? Copenhagen, Denmark: WHO Regional Office for Europe, 2013.

3. Conference Board du Canada. Améliorer les habitudes de vie : des retombées importantes pour la santé et l'économie du Québec. Ottawa (Ontario) : Le Board 2014. Sur Internet : http://www.conferenceboard.ca/e-library/abstract.aspx? did=6647 (consulté le 25 novembre 2017).

4. Hancock T. No quality health care without strong public health. CMAJ 2017 189:E1435. PMID: 29158464. doi: 10.1503/cmaj.171287.

5. Institute for Healthcare Improvement. The IHI Triple Aim Initiative, n.d. Sur Internet : http://www.ihi.org/Engage/Initiatives/TripleAim/Pages/default.aspx.

6. Bergevin Y, Habib B, Elicksen K, Samis S, Rochon J, Adaimé C, et al. Towards the Triple Aim of Better Health, Better Care and Better Value for Canadians: Transforming Regions into High Performing Health Systems. Ottawa, ON: Canadian Foundation for Healthcare Improvement, 2016.

7. Potvin L. La santé publique canadienne en état de siège. [Éditorial] Can ] Public Health 2014;105(6):e401-3. PMID: 25560884. doi: 10.17269/cjph.105. 4960

8. Guyon A, Perreault R. Public health systems under attack in Canada: Evidence on public health system performance challenges arbitrary reform. Can J Public Health 2016;107(3):e326-29. PMID: 27763850. doi: 10.17269/cjph.107.5273.

9. Guyon A, Hancock T, Kirk M, MacDonald M, Neudorf C, Sutcliffe P, et coll. L'affaiblissement de la santé publique : une menace pour la santé des populations et la viabilité du système de soins de santé. [Éditorial] Can J Public Health 2017;108(1):e1-6. PMID: 28425892. doi: 10.17269/cjph.108.6143.

10. Commission de vérité et réconciliation du Canada. Honorer la vérité, réconcilier pour l'avenir : Sommaire du rapport final de la Commission de vérité et réconciliation du Canada. Ottawa (Ontario) : CVR, 2015.

11. United Nations, International Covenant on Civil and Political Rights. Concluding Observations on the Sixth Periodic Report of Canada (CCPR/C/CAN/CO/6). UN Human Rights Committee, 2015. Sur Internet : http://tbinternet.ohchr.org/_ layouts/treatybodyexternal/Download.aspx?symbolno=CCPR\%2FC\%2FCAN \%2FCO\%2F6\&Lang=en (consulté le 26 novembre 2017).

12. Agence de la santé publique du Canada. Histoire. Ottawa (Ontario) : ASPC, 2008. Sur Internet : https://www.canada.ca/en/public-health/corporate/ mandate/about-agency/history.html (consulté le 25 novembre 2017).

13. Agence de la santé publique du Canada. Compétences en ligne. Ottawa (Ontario) ASPC, 2017. Sur Internet : https://www.canada.ca/en/public-health/services/ public-health-practice/skills-online.html (consulté le 25 novembre 2017).

14. Hoffman S. E-mail to Schools of Public Health from Steven J. Hoffman, Scientific Director, CIHR Institute of Population \& Public Health, October 6 2017

15. Government of New Brunswick. Restructuring to Allow Enhanced Alignment of Government Expertise. Press release, August 31, 2017. Sur Internet : http://www2. gnb.ca/content/gnb/en/news/news_release.2017.08.1162.html (consulté le 21 septembre 2017).

16. Canadian Network of Public Health Associations. An Open Letter to the New Brunswick Minister of Health, October 12, 2017. Sur Internet : https://www cpha.ca/nb_openletter (consulté le 25 novembre 2017).

17. Allison S. N.B. public health under siege. Telegraph J. St. John's, NB, October 17,2017

18. Chilibeck J. 'Recipe for disaster': Former top doc slams changes to medical health office. Telegraph J. St. John's, NB, September 14, 2017. Sur Internet : file:///Users/trevor/Downloads/dr-wayne-macdonald-office-of-the-chief-medicalofficer-of-health-new-brunswick-restructuring-.html.

19. Talbot J. Weakening public health makes no sense. Telegraph J. St. John's, NB, October 25, 2017; A7.

20. Government of Ontario. Public Health Within an Integrated Health System: Report of the Minister's Panel on Public Health. Toronto, ON, 2017. Sur Internet http://www.health.gov.on.ca/en/common/ministry/publications/reports/ public_health_panel_17/expert_panel_report.pdf (consulté le 26 septembre 2017).

21. Council of Ontario Medical Officers of Health. Response to the Provincial Consultations on the Report of the Minister's Expert Panel on Public Health. Letter to the Minister of Health and Long-Term Care, October 12, 2017. Sur Internet : http://c.ymcdn.com/sites/www.alphaweb.org/resource/collection/7BDE5E13 2838-4DFE-AF52-28F4A4F9A3F3/COMOH_Response_EPPH_FINAL_121017.pdf (consulté le 25 novembre 2017).

22. Association of Municipalities of Ontario. AMO's Response to the Expert Panel on Public Health. Briefing note, October 12. Sur Internet : https://www.amo.on. ca/AMO-PDFs/Briefing-Notes/2017/Expert-Panel-on-Public-Health-AMOResponse-2017-10.aspx (consulté le 25 novembre 2017).

23. Association of Local Public Health Agencies. Letter to the Minister of Health and Long-Term Care, October 17, 2017. Sur Internet : http://c.ymcdn.com/sites/www. alphaweb.org/resource/collection/7BDE5E13-2838-4DFE-AF52-28F4A4F9A3F3/ alPHa_Expert_Panel_Response_171017.pdf (consulté le 25 novembre 2017). 
sites/www.alphaweb.org/resource/collection/7BDE5E13-2838-4DFE-AF52-28F4A 4F9A3F3/alPHa_Expert_Panel_Response_171017.pdf (Accessed November 25, 2017).

24. Ontario Public Health Association. OPHA's Response to the Expert Panel's Report on Public Health. Toronto, ON: OPHA, 2017. Available at: http://opha.on.ca/ getmedia/66950878-ccd9-4be2-aee8-6633615fcac6/OPHA-Response-to-Reportby-Expert-Panel-October-31-2017.pdf.aspx?ext=.pdf (Accessed November 30, 2017).

25. Ministers of Health and Health Promotion/Healthy Living. Creating a Healthier Canada: Making Prevention a Priority - A Declaration on Prevention and Promotion from Canada's Ministers of Health and Health Promotion/Healthy Living. Ottawa, ON: PHAC, 2010. Available at: http://www.phac-aspc.gc.ca/ hp-ps/hl-mvs/declaration/pdf/dpp-eng.pdf (Accessed September 22, 2017).

26. Strang R, Kendall P, Corriveau A, on behalf of the provincial/territorial chief medical officers of health with the exception of Quebec. Reviving a national prevention agenda is key to sustainability of health care in Canada. CMAJ 2017;189:E1250-51. PMID: 29018083. doi: 10.1503/cmaj.170694.
24. Ontario Public Health Association. OPHA's Response to the Expert Panel's Report on Public Health. Toronto, ON: OPHA, 2017. Sur Internet : http://opha.on.ca/ getmedia/66950878-ccd9-4be2-aee8-6633615fcac6/OPHA-Response-to-Reportby-Expert-Panel-October-31-2017.pdf.aspx?ext=.pdf (consulté le 30 novembre 2017).

25. Ministers of Health and Health Promotion/Healthy Living. Creating a Healthier Canada: Making Prevention a Priority - A Declaration on Prevention and Promotion from Canada's Ministers of Health and Health Promotion/Healthy Living. Ottawa, ON: PHAC, 2010. Sur Internet : http://www.phac-aspc.gc.ca/ hp-ps/hl-mvs/declaration/pdf/dpp-eng.pdf (consulté le 22 septembre 2017).

26. Strang R, Kendall P, Corriveau A, on behalf of the provincial/territorial chief medical officers of health with the exception of Quebec. Reviving a national prevention agenda is key to sustainability of health care in Canada. CMAJ 2017;189:E1250-51. PMID: 29018083. doi: 10.1503/cmaj.170694. 